\title{
Capitalism and Slavery and the Civil War
}

\author{
James Oakes \\ The Graduate Center, City University of New York
}

Walter Johnson, River of Dark Dreams: Slavery and Empire in the Cotton Kingdom. Cambridge: Harvard University Press, 2013. 561 pp. \$35.00.

Edward E. Baptist, The Half Has Never Been Told: Slavery and the Making of American Capitalism. New York: Basic Books, 2014. 528 pp. \$35.00.

Sven Beckert, Empire of Cotton: A Global History. New York: Alfred A. Knopf, 2014. 640 pp. $\$ 35.00$.

Calvin Schermerhorn, The Business of Slavery and the Rise of American Capitalism, 1815-1860. New Haven: Yale University Press, 2015. 352 pp. $\$ 65.00$.

They push in different directions, these two great debates. The first, on the relationship between capitalism and slavery, invites us to consider how closely the two systems were connected, to the point where more and more scholars argue that slavery itself was a form of capitalism. The second, on the origins of the American Civil War, highlights the fundamental difference and growing divergence between the free labor system of the North and the slave society of the South, to the point where some scholars see an irreconcilable conflict between the two. Can these competing tendencies be reconciled? Is it possible to define southern slavery as essentially "capitalist" without losing sight of the crucial distinctions between free and enslaved labor? A number of recent books suggest that scholars have begun to recognize the problem but have not quite figured out how to solve it.

There are actually two distinct debates about capitalism and slavery, one over whether the slave trade and the profits of plantation slavery played a significant role in the Industrial Revolution, and the other about whether plantation slavery itself was or was not capitalist.

Most scholars agree that slavery played at least some role in spurring the Industrial Revolution, especially in Great Britain, particularly in the critical early decades of its development. The slave trade was a massive, highly sophisticated commercial enterprise that required, among other things, a secure financial system that could extend credit and insurance to shippers and a physical infrastructure of docks, port facilities, a shipbuilding industry, and a transportation network within Britain-all of which contributed to the Industrial Revolution. Nor is there much dispute that at crucial points in their early development the textile factories of England benefitted both directly and indirectly

International Labor and Working-Class History

No. 89, Spring 2016, pp. 195-220

(C) International Labor and Working-Class History, Inc., 2016

doi:10.1017/S0147547915000393 
from the growth of slavery and the slave trade. "Slavery did not cause the Industrial Revolution," Barbara Solow has explained, "but played an active role in its pattern and timing." That much is clear. ${ }^{1}$

It is far less clear how much slavery contributed to industrialization and whether the contribution was indispensable. The Industrial Revolution had many causes, and it is no easy thing to parse out slavery's specific contribution. Slavery alone was apparently not enough to cause an industrial revolution, for some of the European nations most deeply involved in slavery and the slave trade-notably Spain and Portugal-were conspicuously slow to industrialize. Viewed from a global perspective, slavery likewise appears as one of a number of factors explaining Europe's "divergence" from other highly commercialized societies - China and India, in particular - in the early modern world. In his influential comparison of England and the Yangzi delta region of China, Kenneth Pomeranz isolates two critical English advantages - coal and colonies (in particular slave colonies) - to explain its ability to finally outpace China's economic performance, though not until the late eighteenth and early nineteenth centuries. Prasannan Parthasarathi, in a comparable study of Europe and India, questions the significance of coal for the industrialization of English textile production and instead emphasizes the mercantilist policies that sheltered English cotton manufacturers from competition with the superior printed cotton cloths produced in India. ${ }^{2}$ This shift from an "Atlantic" to a global perspective entails a corresponding shift away from the traditional focus on sugar plantations to the role of cotton in the development of capitalism, and this in turn raises new questions about the relationship between capitalism and slavery. But the global perspective has not resolved the older question of whether slavery was a necessary (if insufficient) cause of the Industrial Revolution, or whether it was necessary at all. Would Great Britain have industrialized without slavery, though perhaps at a slower pace of in a different way? On this there is still no agreement. ${ }^{3}$

Even if everyone did agree that slavery and the slave trade were indispensable to the Industrial Revolution that would not resolve the question of whether slavery itself was "capitalist." After all, human beings have enslaved one another in societies across the globe and spanning the millennia, yet we can hardly label all of those societies "capitalist." But just as surely, something changed in the early modern era when Europeans carried millions of African slaves across the Atlantic and built their plantations in the New World. Not for nothing have various scholars discerned a new "capitalist" form of slavery in the Americas, a form in which slave labor was rationally organized on a large scale for the systematic production of commodities bound for an increasingly global market. Despite the fact that slave-based sugar plantations originated in the eastern Mediterranean and spread westward to various Atlantic islands off the African coast, a strong case can be made that new world plantations involved a historically novel, if not categorically distinct, form of slavery. The question here is whether calling this new form of slavery "capitalist" risks 
obscuring the fundamental differences between economies based on enslaved rather than free labor.

When Eric Williams opened the modern debate he more or less equated capitalism with the Industrial Revolution. By that standard it would be hard to call slavery "capitalist," because slave-based plantation economies throw down major obstacles to industrialization. A master could certainly put a slave to work in a factory, but plantation slavery was - almost by definition - incompatible with urban and industrial development. So we are back to the original question: Is there some other way of examining the connection between capitalism and slavery while maintaining the distinction between the two?

Here the so-called "transition" debates remain a useful starting point. At almost the same time Williams published his groundbreaking study of Capitalism and Slavery, Maurice Dobb published his influential Studies in the Development of Capitalism. In the exchanges prompted by Dobb's book, as well as a subsequent debate spurred by Robert Brenner, a significant number of scholars agreed that the transition from feudalism to capitalism happened first in the countryside. An "agricultural revolution" created a new form of society based on free labor. Liberated from feudal restraints - or perhaps we should say, stripped of feudal protections - farmers began responding to unprecedented pressures to increase their productivity and then selling their growing surpluses to an exploding population of wage laborers in nearby cities. ${ }^{4}$

These new workers were not only producers. "As the peasants became landless," R. H. Hilton explained, "they not only became labourers. They became consumers." 5 The agricultural revolution thus cleared the path for a "consumer revolution," rendering England unusually receptive to the cheap, newly available commodities - coffee, tea, cocoa, and, above all, sugar-produced by slaves on New World plantations. But, as Jan De Vries noted, the stimulus worked only "where the domestic economy was responsive to the new opportunities thus created." In this scenario, the capitalist transformation preceded - and was the necessary precondition for-both slavery in the New World and the Industrial Revolution in England. ${ }^{7}$

Eric Hobsbawm was one of the first scholars to highlight the problems raised by the simultaneous development of slavery and free labor in the early modern world. It was one thing to trace the "progressive replacement of feudalism by capitalism" within Western Europe, Hobsbawm argued, but the effects of the transition were very different outside capitalist development's 'heartland':

In fact, large parts of the Americas were turned into slave economies to serve the needs of European capitalism, and large parts of Africa were pushed back economically through the slave-trade; large areas of eastern Europe were turned into neo-feudal economies for similar reasons .... The net effect of the rise of European capitalism was therefore to intensify uneven development, and to divide the world ever more sharply into two sectors; the 'developed' and the 'under-developed' countries, in other words the exploiting and the exploited. 
The triumph of capitalism at the end of the 18th century put the seal on this development. ${ }^{8}$

Where Williams made capitalist development dependent on slavery, Hobsbawm reversed the power relationship and argued that slave plantations came into existence "to serve the needs" of capitalism. This is especially clear in the case of cotton. For at least a century before the Industrial Revolution, Indian peasants, laborers, and weavers dominated the extensive global market in cotton. In an effort to compete with the highly desirable Indian printed cloth, English manufacturers began mechanizing cotton spinning and weaving decades before the first southern slaves produced their first cotton bolls. On the face of it, it looks as though southern cotton plantations arose in response to the Industrial Revolution, not the other way around. Furthermore, the market the British were trying to capture was largely domestic, meaning that a robust consumer base already existed in England. Robert Brenner and Christopher Isett draw the appropriate conclusion: The Industrial Revolution in Britain was itself the product of the prior capitalist transformation of the countryside. ${ }^{9}$ In this account, Hobsbawm is vindicated. Capitalism, not slavery, was the truly revolutionary force and not merely by spreading free labor around the world. As it spanned the globe, capitalism drove indigenous peoples from their lands, put slaves to work on plantations in the Americas, and reduced eastern European peasants to a second serfdom. Furthermore, it underdeveloped Africa and destroyed the centuries-old market for Indian fabric in places like Syria and Anatolia. It was a devastating indictment of capitalism, all the more so because it was so persuasive.

But was Hobsbawm too persuasive? In drawing such a sharp, categorical distinction between the developed and the underdeveloped worlds, between "core" and "periphery," did Hobsbawm underestimate the "capitalist" elements of production that were intrinsic to plantation slavery as such? There's a reason slave plantations are sometimes referred to as "factories in the fields." New World slavery was arguably the most highly rationalized system of labor exploitation in the preindustrial world. It was not simply that the slaves spent their working lives systematically producing commodities prized by consumers in England and the northern states. Slave purchases were financed by commercial loans and private mortgages, creating debts that could be repaid only by increased production for the market. Only recently have scholars begun to pull on these threads to explore the implications of a labor system in which the workers were owned as collateralized private property.

We now have a much better understanding of the "circuits of capital and credit" upon which the southern slave economy depended, with crucial consequences for the lives of slaves and masters alike. Debt made the slaveholders highly sensitive to the pressures of the global cotton market, forcing them to compete with one another to increase output. Market pressure all but required cotton planters to adopt new seed varieties that produced more-and more "pickable"-cotton, resulting in a quadrupling of productivity on cotton 
plantations in the decades before the Civil War. That same competitive pressure pushed the slaveholders onto the far more productive soils of the Alabama and Mississippi black belts, a massive migration that entailed the brutal dispossession of Native Americans from the Southwest and the systematic breakup of slave families and communities. Slave-based debt made the owners vulnerable to periodic fluctuations in the world cotton market, especially the severe depression of 1839-1843, when thousands of plantations went bankrupt, resulting in still more disastrous dislocations in the lives of slaves. The slaveholders responded to low prices by increasing the amount of cotton they produced. ${ }^{10}$ This was precisely the kind of dependency that Charles Sellers put at the heart of the "Market Revolution."

Notwithstanding the sometimes calamitous fluctuations in the cotton market, world demand for the fiber was so strong that in the long run it pulled ever larger numbers of slaves out of tobacco, wheat, and rice into the routinized labor of cotton production. For all of these reasons and more, a growing number of historians are inclined to describe southern slavery as, in and of itself, capitalist.

Yet the analogy of plantations to factories is also misleading. There were crucial differences between the political economy of slave and free labor-differences that ultimately led to a catastrophic Civil War and one of the most violent emancipations in the hemisphere. At the heart of that difference was the fact that slaves were owned as property whereas in the North, laborers owned themselves and worked either as independent farmers and artisans or as free wage laborers. From this basic distinction, a number of conspicuous regional distinctions emerged. Because credit was based on slaves rather than land, for example, the southern states developed a "regionwide" system of debt financing that had no counterpart in the North. Slave property also gave masters a powerful competitive advantage in the settlement of western territories. Unlike northern farmers who had only the labor of their own families to rely on and relatively little capital, the slaveholders were "settlers with means" who easily snatched up the best lands with the readiest access to market and could afford to spend several years clearing the lands for extensive cotton production. Moving to more fertile lands and adopting new varieties of seeds certainly increased the productivity of slaves in the cotton South, but unlike wheat producers in the North southern masters had little incentive to replace slaves with machines, and that meant that there were sheer physical limits to how much labor masters could wring from their slaves without killing them. ${ }^{11}$

Although plantation slavery was a thoroughly commercialized system of production, it had paradoxical elements. Slaves had to be kept busy year-round, for example, so the slaveholders filled in the gaps in the staple crop schedule by making their plantations self-sufficient in foodstuffs and in the process insulating themselves from some of the disruptive effects of a fluctuating market. And because self-sufficiency meant, among other things, that the consumer market in the South was suppressed, the cotton states had few cities and market 
towns. With relatively few factories, the cotton South attracted few immigrants. In the North, farmers could safely increase their commercial production because growing cities and factories with an expanding population of immigrant wage laborers provided a steady market for the products of the agricultural hinterland. But in the South there were few such opportunities for yeoman farmers, with the result that slaveless farms in the South were, on average, half as wealthy as yeoman farms in the North. Wealth in the North was equitably distributed by historical standards, whereas the southern wealth distribution was comparable to extreme levels of inequality then prevalent in England and France. U.B. Phillips once said that slavery made fewer fortunes than it made men, but in fact it made extraordinary fortunes. In 1860 two-thirds of the millionaires in the United States were southern planters. But was this a sign of regional prosperity? A skeptical Keynesian, looking at those statistics on the exceedingly skewed distribution of southern wealth, might conclude that this was an unhealthy way to organize an economy. No doubt slavery made the slaveholders rich, but it also made the South poor.

The hybrid nature of the slave economy presents historians with a tricky problem. How do we write a history of slavery and the Civil War that accounts for both the similarities and the differences between capitalism and slavery, a history that links slavery to the expanding global market without homogenizing everything within the market's reach? Walter Johnson, Edward Baptist, Calvin Schermerhorn, and Sven Beckert offer different resolutions to the dilemma, some more fruitful than others. Baptist has the most successful political account of the sectional crisis, but he makes unwarranted claims about the economics of slavery. Schermerhorn shifts the focus of attention from plantation labor with his detailed reconstruction of the business of slave trading, but he can't explain what was unique about slave trading or why it provoked so much hostility among northerners. Sven Beckert sees the Civil War as a fundamental conflict between "industrial capitalism" in the North and "war capitalism" in the South, but despite his emphasis on the role of the state he has no apparent interest in the politics of slavery and hence no adequate account of the war itself. Johnson's book is the least persuasive, in part because he disputes the premise that the Civil War is something historians should be explaining and in part because of his apparent lack of familiarity with some of the basic facts of American economic history. And in one way or another, all of these authors are content to demonstrate the connections between capitalism and slavery while presenting little or no evidence that might help clarify the significance of those connections.

Johnson's River of Dark Dreams is an evocative history of the spread of slavery into the Mississippi Valley. Thomas Jefferson's dream of an "empire of liberty," of independent yeoman farmers shielded from the corrupting influence of the global market, serves as the ironic backdrop. It was a dream that was quickly displaced by the nightmare of what Johnson calls "slave racial capitalism." The most effective parts of the book feature powerful descriptions of life and land in the Mississippi Valley. Johnson tells of how trees were uprooted, 
rows dug, seeds planted; of bugs and weeds and rust; of cotton harvested and bales packed, mislabeled, and hauled laboriously down to the river. Alongside the advice manuals urging planters to rationalize their farming operations Johnson intersperses gruesome accounts by former slaves of what proper "management" often meant in practice. He follows the slaveholders' obsession with productivity and profit as it reached outward from their plantations and into the wider world - to textile manufacturers in Liverpool, to bankers and shippers in New York, to the factors in New Orleans that advanced lines of credit, to the steamboat operators who used high pressure engines to force paddle-wheelers upriver, against the current, over the snags and sandbars of the Mississippi. Cheaply built and pressed beyond their limits, the steamboats had a tendency to blow up, and Johnson opens his book with a metaphor that neatly captures the twin explosions of cotton production and steamboat engines. His introduction is called "Boom."

But as an interpretation of the cotton South and an analysis of the slave economy, River of Dark Dreams is far less successful. Johnson presents his book as an "alternative vision" of southern slave society. Traditional accounts, he complains, define the South as the "section" that eventually crashed and burned with the Confederate States of America. Studies of the sectional crisis are supposedly distorted by a "nationalist" bias that obscures slavery's imperial impulses. Johnson rejects these approaches as "anachronistic" and "teleological" $(15-16,420)$. The Old South was not becoming the Confederacy, he argues, at least not according to its proslavery avatars in the Mississippi Valley. They imagined a destiny for themselves as the imperial rulers of Mexico, Cuba, and Nicaragua. In Johnson's telling, the history of the slave South ought not to be traced through a tedious litany of familiar events like the Missouri Crisis, the Compromise of 1850, and the Kansas-Nebraska Act, but through the transition from expansionism to imperialism. Accordingly, Johnson's book ends not with the dissolution of the Union but with several chapters on the various proslavery filibustering invasions of Latin America and the movement to reopen the African slave trade. Johnson appears to believe that tracing the origins of a proslavery empire that never came into being is somehow less teleological (and less anachronistic) than the history of the Confederate nation that the South actually became.

It has to be said that Johnson's description of the historiography borders on caricature. It's as though "standard" accounts rarely mention things like the Louisiana Purchase, the Mexican War, filibustering expeditions to Nicaragua, or the Ostend Manifesto. In fact, these are familiar features of every standard history - whether by Allan Nevins, David Potter, or James McPherson. The difference is that their accounts explain the secession of eleven slave states that formed the Confederate States of America, whereas Johnson explains things that never happened-how the slaveholders took over Nicaragua, annexed Cuba, and reopened of the Atlantic slave trade.

In addition to his imaginative new history, Johnson provides an explanation for his alternative trajectory. The prime mover behind proslavery imperialism, 
he argues, was a slave economy hobbled by a number of intrinsic weaknesses. "In order to survive," Johnson concludes, "slaveholders had to expand."

Cotton mono-cropping stripped the land of vegetation, leached out its fertility, and rendered one of the richest agricultural regions of the earth dependent on the upriver trade for food ... . [I]t was in response to these material limitationsand in response to enslaved people's response to these limitations - that Valley slaveholders sought to project their power outward in the shape of pro-slavery imperialism in the $1850 \mathrm{~s}$.

Fifty years ago these "material limitations" would have been familiar to historians of the South. The planters overinvested in slaves, cotton depleted the soil, the South could not feed itself and as a result the slaves were severely malnourished. Johnson cites these myriad weaknesses as the explanation for the depression of the early 1840 s as well as the proslavery imperialism of the 1850s. But his account must come as a surprise to anyone familiar with the scholarship on southern economic history from the past several decades. Cotton did not deplete the soil and so cannot account for southern expansionism. The crescentshaped "black belt" - named for its rich dark earth - is still there, visible to anyone who wants to see it on Google Earth. Indeed, the amount of southern land devoted to cotton farming within the former Confederate states doubled between the end of the Civil War and 1890 and then doubled again by 1920 . Furthermore, planters did not overinvest in slaves: It was established decades ago that higher slave prices reflected the growth in world demand for cotton, and recent scholarship has demonstrated significant increases in slave productivity on cotton plantations. Johnson acknowledges that productivity increased but does not realize that this destroys the overinvestment thesis. Nor does Johnson seem to be aware of the equally well-established fact that the cotton South did not have to buy food from the western states because the slaves grew enough corn and raised enough pork to feed themselves. There is dispute over whether their diet was lacking in certain essential nutrients, but there is no evidence to support Johnson's thoroughly undocumented claim that slaves in the Mississippi Valley were "starving." Indeed, the claim reveals how completely Johnson misconstrues the problem of underconsumption. The home market was suppressed in the slave South not because the slaveholders weren't buying enough food. It was suppressed because the planters were buying hardly any food because the plantations were self-sufficient. ${ }^{12}$

Having located the origins of proslavery imperialism in an antiquated account of slavery's economic weaknesses, Johnson then wheels around in the opposite direction to explain the cotton boom of the 1850s. Suddenly a slave system that was riddled with "material limitations" becomes a modern, highly productive system of capitalist exploitation. There are problems here as well, especially in Johnson's inapt comparison of the "advanced" technology that reduced transaction costs in the South with the "backward" technology that increased labor productivity in New England. There's nothing distinctively 
modern about transportation improvements that reduce the cost of moving goods to market. Phoenician sailors reduced transaction costs, as did the Appian Way and so did the steamboats that plied the Mississippi. But none of them increased labor productivity the way textile mills did, despite the fact that the mills in both old and New England initially relied on water power rather than steam engines.

Johnson is on firmer ground in his claim that the cotton boom proved as disruptive in its own way as the bust. High slave prices, the declining proportion of slaveholders, the steady drain of slaves from the Upper South into the cotton belt-all prompted fears that the nonslaveholders and the border states would not remain loyal to slavery. If proslavery imperialism was the solution to the weaknesses of the slave economy in the 1830 s and 40 s, what would be the response to slavery's robust performance in the 1850s? "Increasingly, Mississippi Valley slaveholders (and others) sought fixes for these contradictions outside the confines of the United States. Cuba was the first target." Prosperity, in short, had exactly the same effect as depression. All economic roads led to proslavery imperialism.

Johnson is merely the latest in a long line of scholars who have struggled to capture the antinomies of the slave economy - an ancient system of labor transformed into a highly rationalized system of production. But Johnson's own approach cannot overcome the limitations of its own premises. He invokes the slave economy - its phantom weaknesses as well as the very real perils of prosperity -in order to explain the imperial fantasies of a handful of crackpots. Filibusters like Matthew Maury, Narciso Lopez, and William Walker had their fans and got plenty of attention, but they didn't get what they wanted. Having complained about the "sectionalism" of previous accounts, Johnson carves out his own "section" of the slave South, divorcing the lower Mississippi Valley from the eastern and border slave states that were hostile to the idea of reopening the slave trade and had little taste for imperial adventurism.

This is where Johnson's dismissal of "threadbare" histories of the sectional crisis proves so unsatisfactory. The eleven slave states that declared themselves a Confederacy in 1861 actually banned the Atlantic slave trade in their constitution, something not even the US Constitution did. As soon as the Civil War began, it was the Union, not the Confederacy, that proposed grabbing Cuba from Spain. Instead, the confederate states struggled through four years of war to create an independent nation, but not an empire. They embarked on no imperial projects-even when all but invited by Mexico to do so. If that history, the actual history of what actually happened, was related in some way to the nature of the slave economy, Johnson has failed to explain it.

Readers who are unwilling to abandon the familiar sequence of events leading up to the Civil War will find vindication in Edward Baptist's The Half Has Never Been Told. It's all here: The debates over slavery at the constitutional convention, the Missouri Crisis, the Gag Rule, the Mexican War, the Wilmot Proviso, the Compromise of 1850, the Kansas-Nebraska Act, the Dred Scott decision, the emergence of the Republican Party, the election of Abraham Lincoln, 
and, finally, the secession crisis. There's been some sniping about Baptist getting some dates wrong, and some footnotes are out of place, but in general Baptist's rendition of the politics of slavery is accurate and remarkably free of some of the distortions that have been all too common in the literature. He appreciates the seriousness of the Republican threat to slavery and therefore rejects the familiar description of secession as an outbreak of mass hysteria. The conflict over slavery was real, and in 1860 it had reached a deadly impasse.

More impressive still is the way Baptist grounds his political history in the social and cultural history of slavery. He abandons the methodological zealotry that has for so long hobbled the history of slavery. Political historians tend to ignore social history; social historians tend to ignore political history; hardly anybody reads economic history; cultural historians too often write as if totally unmoored from any standards of significance that political, social, or economic history might impose. Baptist deploys all of these approaches without letting any one of them overrule the implications of the others. Over the course of four hundred pages, The Half Has Never Been Told weaves back and forth between day-to-day life on slave plantations, the Bank War, the internal workings of the domestic slave trade, the fracturing of the northern Democrats, the culture of the slave quarters, and John C. Calhoun's absolutist defense of slave property.

It would have been easy for such a broad-based narrative to spin out of control, but Baptist maintains discipline thanks to his keen eye for the significance of chronology. The pace of the book is driven by three major developments. The first is the dramatic expansion of the cotton economy, an expansion Baptist attributes not to slavery's intrinsic weaknesses but, on the contrary, to the slaveholders' brutally effective imposition of a speed-up that resulted in the quadrupled productivity of southern slaves between 1800 and 1860 . The second is the steadily heightening tension between the North and the South over slavery's expansion. The third development, a critical one even though Baptist devotes far less space to it, is what he calls the "diversification" of the northern economy, which he dates to the aftermath of the Panic of 1837. This northern departure shifted the balance of economic and political power between the sections, paving the way for the Republican victory of 1860 . This may not be the most startling reinterpretation, but the fact is that there have been remarkably few scholars - William Freehling is one notable exceptionwho have so skillfully woven together the different pieces of a large and complicated story.

Where there is novelty in Baptist's account, it resides more in the individual pieces than in the overall interpretation. It will be interesting to see how social historians respond to Baptist's severe reduction of the significance of day-to-day resistance among slaves. They may have tried malingering, but the masters kept such close tabs on the workers that, in the end, slaves were picking four times as much cotton per hand as their ancestors had done. Slaves tried putting rocks in their cotton, but the owners were on to them. The slaves knew full well that anyone who feigned illness, broke tools, or slowed down would be swiftly and 
severely "tortured." Fathers may have wanted to fulfill their traditional roles but they could not help but be emasculated by a system in which their wives were raped and their children brutalized-and there was almost nothing the men could do to stop it.

Ironically, the least persuasive parts of the book are the ones Baptist is most keen to highlight, especially his claims about the economic history of slavery. Sometimes skepticism is aroused less by the facts Baptist emphasizes than by his explanation for them. In 1987, for example, Robert Fogel attributed the increase of the slaves' productivity to the adoption of the gang labor system on southern plantations, which Fogel likened to an industrial "speed up."13 This is not all that different from Baptist's interpretation, which likewise focuses on the slaveholders' imposition of a ruthlessly rationalized system of labor control, except that Baptist adds "torture" to the rationalized mix. It is well known that many masters kept detailed records of the amount of cotton harvested by each "hand" each day. But Baptist goes further by claiming that whenever a slave's daily harvest increased, he or she set a new standard for every subsequent day's picking (the speedup), and that hands who failed to meet the new standard were whipped-"tortured." Most provocatively, Baptist claims that this systematic torture of slaves is the primary explanation for the productivity increases in the cotton South.

But Fogel's critics were quick to point out that gang labor was not uniformly adopted on southern plantations and that productivity increased on small farms as well as large plantations, whether or not slaves worked in gangs. Some planters kept elaborate records and some didn't. Some planters whipped their slaves frequently, and some almost never did. Gavin Wright showed that productivity was higher on plantations in the "black" belt where enslaved women were also more likely to work as field hands. Once upon a time, historians attributed this geographical distinction to the supposed primacy of the "task" system in the east and the gang system in the southwest, but more recently a number of scholars - Philip Morgan, John Hebron Moore, Peter Coclanis, and Gavin Wright - have suggested that most planters relied on a combination of different systems of labor organization. ${ }^{14}$ More persuasive than the gang labor thesis are the pioneering investigations by Alan Olmsted and Paul Rhode into the rapid adoption of hybrid seed varieties that made cotton plants more fruitful, their bolls more easily harvested, especially in the superior soil of the black belt. ${ }^{15}$

Olmsted and Rhode's work on biological innovation in American agriculture is so impressive that it has rapidly garnered widespread support among students of the slave economy. Their findings explain why cotton plantations in the southwest were more productive than cotton plantations in the southeast. They explain why women and children were more widely used as field hands in areas most suited to more "pickable" varieties. Moreover, their scholarship places southern cotton planters squarely within a broader tradition of American farmers, North and South, who were similarly cross-breeding wheat, corn, and livestock to maintain or increase agricultural productivity. In short, cotton 
planters who constantly experimented with new seed varieties were well within the mainstream of capitalist farmers throughout the country. Since this is one of the central points Baptist wants to make - that northern and southern capitalism were more similar than different-one would have expected him to embrace Olmsted and Rhode. Instead Baptist discounts the significance of their findings and proceeds to yank the southern planters out of the national pattern by claiming that the productivity increases on slave plantations were caused not by hybrid seed varieties, but by the systematic use of torture. Wheat and corn farmers, cattle ranchers, dairy herdsmen - they all managed to improve their productivity through hybridization. Only southern masters relied on torture.

To prove his point, Baptist would have to present far more evidence than he does. The writers who promoted more systematic management of slaves argued that the rationalization of plantation routine would require less, not more, whipping. Richard Dunn's recent case study of the Tayloe plantations suggests that, in at least some cases, the reformers were correct. Tayloe established a new cotton plantation in Alabama in the 1840s and hired a steady, reliable overseer to manage the operation. He kept all the records Baptist could hope for, but they don't reveal a pattern of systematic torture. On the contrary, by 1851, when the Tayloe plantations were at their most productive, the overseer boasted that "the Negroes have worked better this year than they have ever since I have been on the farm and with less trouble. There has not been one of them whipped since we commenced working the crop." ${ }^{\prime 6}$ In principle, that was the way rational management was supposed to work. But of course, the overseer's boast implied that in previous years he had whipped slaves, and every historian of the slave South knows about planters like Bennet Barrow who sadistically whipped their slaves all the time. So the point is not to deny that violence was a basic element of the slave system. It was. The point is that Baptist goes too far when he makes sweeping assertions about the universal use of "torture," especially when he claims that it was the basis for the increase in slave productivity.

Baptist's most extravagant and least persuasive claim is that all of the prosperity of the American economy derived from slavery. There's barely a sentence in his book that could justify such a claim, however, and for a very obvious reason: Any study aimed at calculating the impact of slavery for northern economic development would not be a book about slavery at all. It would have to be a book about the North. At the very least, The Half Has Never Been Told would require a second half that examines the process of economic development in the free states and demonstrates precisely when and how that process depended on southern slavery. That will not be easy, at least not based on the extraordinary scholarship of the last generation or two.

Consider the outcome of the debate among scholars that raged through the 1980s over the transformation of the northern countryside. There is now broad agreement that farmers in the northern colonies always produced surpluses for sale although they were careful to limit their market involvement in ways that protected their economic independence. That began to change in the 1790s, 
when New England farmers found themselves trapped by the competitive demands of a rapidly commercializing agriculture in ways that forced them to steadily increase their productivity. The process spread westward, and the northern countryside was thoroughly transformed by 1845 , when wheat farmers began to mechanize production at an astonishing pace. ${ }^{17}$ Northern agricultural productivity skyrocketed even as the rural economy extruded "surplus" population into cities and factories at a rate that outpaced number of immigrants - who were by then streaming into the North by the millions. Those landless workers were attracted by a new form of free labor that had simultaneously developed in the North in the decades following the American Revolution. Apprentice contracts became wage contracts, indentured servitude disappeared, and slavery was abolished. By the 1820s "a day's pay for a day's work" became the norm - and with it a uniquely mobile population of free laborers was created. Within the space of a single lifetime forms of long-term labor subordination that had existed for centuries, even millennia, were dramatically overthrown. "Thus it was not slavery," Gavin Wright has concluded, "but the post-Revolutionary abolitions and the exclusion of slavery from the Northwest Territory that launched the American economy on its modern trajectory." 18 Put these two developments togetherthe transformation of the northern countryside and the rapidly expanding population of highly mobile wage laborers-and the stage was set for the dynamic interaction of the city and the country that so many scholars have seen as the preeminent characteristic of northern economic development. ${ }^{19}$

None of this appears in Baptist's account. Instead, he disinters an older story that told of industrialization "spiraling outward" from the textile mills of Massachusetts and Rhode Island - a story long ago abandoned by most economic historians. Before we revert to this traditional account, however, Baptist will have to explain where historians like Diane Lindstrom went wrong when they adduced evidence that the southern trade was relatively unimportant to the economic development of the Philadelphia. He would have to explain away the evidence that "metropolitan industrialization" overshadowed New York City's ties to slavery, that economic development bound the city much more closely to the wheat and dairy farmers in the Hudson, Mohawk, and Ohio River valleys-as most scholars now believe. He would have to explain away the extraordinary maps in William Cronon's Nature's Metropolis demonstrating the way railroads spread out from Chicago bringing wheat farmers throughout the Midwest into the city's powerful economic orbit-an orbit that reached back to the east coast and all the way to Europe but that barely touched the slave states. In these accounts the history of the northern economy after 1776 is one of growing independence from slavery, a fact of no small significance for the origins of the Civil War.

In addition to explaining where generations of scholarship on northern economic development have gone wrong, Baptist would have to tell us where he's getting his numbers. He points out that in 1836 cotton production represented about five percent of the gross domestic product. This is a widely accepted statistic, having been calculated in several different ways by a number of 
different scholars. But its significance is not self-evident. Is five percent a lot or a little? Instead of addressing that question, however, Baptist quickly moves on to the second- and third-order effects of cotton in the larger economy, and here a number of problems arise. To begin with, second-order effects are notoriously difficult to calculate, and by the time you get to third-order effects, you might as well be floating in the clouds. At the very least, such calculations require extensive justification and analytical precision - none of which Baptist provides. In fact, he provides no sources whatsoever for any of his calculations. From his brief description he seems to be adding the proceeds of wealth transferssuch as the sale of slaves - to the figures for output. Finally, having posited suspiciously large second- and third-order effects, he then adds those effects to the original GDP statistic, and suddenly, without explanation, five percent becomes fifty percent. Obviously if you applied the same technique to every other northern enterprise - the granaries of the Midwest, the printing shops of Manhattan, the iron foundries of Pennsylvania, the small manufacturers of Philadelphia, the meatpackers of Cincinnati, the dairy farmers of the Hudson Valley, the wheat farmers along the Erie Canal-you would end up with five thousand percent of the GDP. If Baptist's numbers were even remotely accurate, the abolition of slavery during the Civil War would have been accompanied by a catastrophic collapse of the northern economy.

Baptist takes his title from Lorenzo Ivy, one of the many elderly ex-slaves interviewed by the WPA in the 1930s. Ivy and his mother were originally owned by a "mean" master who broke up families left and right. Ivy told the interviewer that the only good thing his heartless owner ever did, and did unintentionally, was to sell the boy and his mother to his father's owner. This endless buying and selling of slaves - the coffles of chained human beings who passed by Ivy's Virginia home year after year - is the "half" of slavery's history that Baptist claims has never been told. But Baptist himself doesn't tell the other half of the ex-slave's own story. Ivy described his new master as a good man who kept the slave family together, recognized the boy's talent as a shoemaker, sent him off to Lynchburg to learn the trade, and let Ivy hire himself out. Ivy's mistress taught the boy to read. When the Civil War ended, Ivy was sufficiently literate and skilled to set up his own shoemaking shop and attend Hampton Institute. He was at Hampton when his former master died, and Ivy was upset that he was unable to attend the funeral to pay his respects. ${ }^{20}$

Now, was Ivy any less of a slave for his having been owned by a "good" master? Adolph Reed makes the point in his review of Quentin Tarrantino's potboiler, Django Unchained. Even if none of the violence Tarrantino splashes onto the screen took place, Reed notes, the slaves would still be slaves. Ivy was not freed until 1865, after Lee surrendered at Appomattox. Until then his master owned Ivy as his personal property, even if he was good enough not to sell him.

Baptist knows this. Indeed, it is one of the strengths of his book that he comes closer than most historians to seeing the connection between the status of slave laborers as property and the sectional crisis over slavery. He 
understands, for example, that the heart of Calhoun's defense of slavery was the inalienable right of property. But Baptist only distracts attention from the considerable merits of his book first by replacing the language slaves themselves used-"plantations" and "whipping"-with overwrought neologisms like "slave labor camps" and "torture" and by making implausible claims about the slave economy and its larger economic significance.

Fewer than half of the South's slaves worked on cotton plantations, and this raises a number of questions. Were systematic speedups and routinized torture widely deployed on the hemp farms in Kentucky, the wheat farms of Maryland, the tobacco plantations of North Carolina? Are cotton plantations the best place to look to find answers to the most important questions about capitalism and slavery? How many of the characteristics we assign to the slave economy were actually a function of the cotton economy? It's well known, for example, that the technical barriers to the mechanical harvesting of cotton were not overcome until the twentieth century. For that matter, are plantations a distraction? Over the centuries southern plantations relied on various forms of labor - indentured servitude, sharecropping, wage labor, and slavery. What distinguished slavery as a labor system was the fact that the workers were the moveable property of their masters. It may be, then, that the best place to get at the beating heart of the slave economy is not the Big House at the center of the cotton plantation but the Auction House at the center of the domestic slave trade.

That's the premise of Calvin Schermerhorn's highly informative new book on The Business of Slavery. If southern slavery was a capitalist enterprise, what better place could there be to observe its workings than the domestic slave trade? This is not a new subject for scholars, nor is it a new theme. Nearly a century ago Frederick Bancroft replied to U. B. Phillips' romanticized interpretation of southern slavery with a detailed study of Slave Trading in the Old South, a book that remains valuable for the wealth of information it contains. More recently, Michael Tadman reignited the field with his path-breaking Speculators and Slaves, establishing the basic contours of the domestic slave trade as it developed and changed over time. Since then, Stephen Deyle traced the political significance of the slave trade within the Old South, Robert Gudmestad uncovered its cultural significance among white southerners, and Walter Johnson, in his first book, attempted to recover the subjective experience of selling slaves and being sold. Schermerhorn's book is a welcome addition to this already impressive body of scholarship and now takes a place alongside Tadman's as the indispensable starting point for future scholars.

Schermerhorn's focus is on the slave-trading firms themselves. In a series of detailed case studies, more or less chronologically arranged, he reconstructs the process by which individual merchants built their businesses and established an elaborate network of contacts-local, regional, national, and internationalthat made slave trading into an efficient and profitable enterprise. He is careful to note regional variations and changes over time. Louisiana sugar plantations were heavily capitalized and therefore more dependent on credit than others, and the New Orleans slaving business was often irrationally speculative 
in ways that are eerily familiar. Like collateralized debt obligations, a hodgepodge of loans on land, slaves, and other properties, was sometimes bundled into bonds that were then sold through Barings in London, which in turn marketed them to unwary buyers throughout the continent. Not surprisingly, a credit crunch or a downturn in the sugar market could send speculative firms collapsing into bankruptcy. But other businesses were more careful, and in a long and devastating chapter on the slave-trading firm of Franklin \& Armfield, Schermerhorn shows us how the company built a reputation for reliability by creating its own credit system, establishing its own supply chain, and vertically integrating its operation, so that it could move slaves through the market reliably and efficiently.

It's all disturbingly familiar, and Schermerhorn knows it. He likens Franklin \& Armfield's credit branch to the auto loan subsidiary that General Motors established more than a century later. He could as easily have pointed out that slave traders learned to bundle their human merchandise into standardized grades in much the same way that Chicago grain dealers were figuring out how to categorize wheat.

Except that it wasn't wheat and it wasn't cars. Slave trading was unlike any business, then or since, because the merchandise was human beings. They were held in jails while awaiting "transport." They were beaten when they resisted. They got smallpox and dysentery. Their families were destroyed. Everyone at the time noticed the difference. No one was demanding the abolition of grain silos the way abolitionists regularly called for the suppression of the domestic slave trade. Mainstream politicians like Abraham Lincoln denounced the "property principle" that treated human beings as though they were mere commodities. Without admitting as much, Schermerhorn depends on this same reaction from readers. He wants us to appreciate how modern and sophisticated the slave trade was as a business, while at the same time he knows that we will recoil in horror because this particular business strikes us as so evidently disgusting. Put differently, Schermerhorn's ability to evoke this reaction from readers depends on the premise that there was something about buying and selling human beings that was unique, or at least uniquely disturbing, to bourgeois sensibilities.

Schermerhorn's meticulous reconstruction of the national and international connections established by southern slave trading firms is illuminating in its detail, but its significance remains obscure. The firms opened branches in Philadelphia and New York. Their representatives sailed to Liverpool to do business with cotton brokers before moving on to London where they struck deals with financiers to market their bonds in slave-based debt. Schermerhorn has no trouble tracing those connections. What he cannot do is establish how important those connections were. He can show that a wildcat firm in New Orleans relied heavily on Barings to market its junk bonds, but he cannot say that this was a common practice among southern firms, nor can he show how important that aspect of the business was to Barings - much less to the British financial sector as a whole. There's good reason to wonder about this. 
To begin with, most of the receipts from cotton sold in Britain ultimately made their way back into the South where planters used them not to build factories or mechanize production, but to do more of what they were already doing - they bought more slaves to plant more cotton to buy more slaves, and so on. But what about the receipts from the cotton trade that stayed in the North as the profits of merchants and bankers? It would appear that not very much of that money went into productive activity, either. Most of the returns from the cotton trade were instead used to speculate in western lands or to purchase railroad bonds. No doubt railroads were important to northern economic development, and in that sense the profits of slavery fueled economic growth. But as Albert Fishlow demonstrated decades ago, railroads did not cause development, they followed it. And as generations of historians have noted-and dozens of college textbooks make vividly clear-the map of American rail lines in 1860 reveals not merely the connection between the northeast and the northwest, but their economic interdependency. Surely it tells us something that on the eve of the Civil War most of the tracks ran east and west, not north and south.

Then, too, Schermerhorn's own evidence suggests that the southern financial system was largely self-contained. Slave-trading firms financed their loans to buyers primarily from their own receipts, transactions rendered more fluid and predictable with the help of local and regional banks. The obvious reason for this is that the southern credit system was based on a form of wealth-slave property-that was, in Gavin Wright's words, "unavailable to nonresidents of the region." Northern farmers had no comparable basis for credit. Wright was endorsing the important findings of Richard Kilbourne: the Old South's credit system was based overwhelmingly on "liquid" assets in slaves, rather than land, and the domestic slave trade involved cash transactions between the slaveselling states of the east and the slave-buying states of the southwest. Regional banks facilitated those exchanges, but when slavery collapsed, so did the "regionwide network of private investment banks.",21

Schermerhorn makes a strong case for the modernity and sophisticationand hence the familiarity - of the domestic slave trade, but there's an equally strong case to be made for its uniqueness, its regional particularity. The slave market was a southern market, and it did not function the same way or do quite the same thing as a labor market. This is not to say that slave trading was disconnected from global financial networks. In the end, the ability of southerners to buy and sell slaves depended on the receipts flowing back into the South from the sale of cotton, tobacco, and sugar to distant markets, mostly in England, and that cash flow depended in turn on sound financial institutions of the Atlantic world. The question is whether this made London banks dependent on slavery, or slavery dependent on London banks. There's nothing in Schermerhorn's book that allows us to answer that question.

Where Schermerhorn looks at the slave economy on the ground-from Natchez to Nantes, as it were-Sven Beckert's Empire of Cotton steps back and reveals the global interconnections from 50,000 feet above the earth. It is 
in many ways a dazzling sight. From that angle of vision Beckert notices the crucial distinction between merchant and industrial capital that others gloss over. $^{22}$ It allows him to investigate the close relationship between slavery and capitalism without collapsing the distinction between the two. And by broadening his sights beyond the Atlantic, Beckert offers some arresting new observations.

Simply by shifting the focus from sugar to cotton, for example, Beckert implies a thorough-going revision of the Williams thesis. In Capitalism and Slavery, as in most accounts since then, sugar was the crucial commodity in the story of capitalism's rise to power. But in recent years a number of scholars have suggested that cotton was at least as important, possibly more so. Prasannan Parthasarathi had highlighted the centrality of Indian cotton for global trade in the seventeenth and eighteenth centuries. The importance of cotton is likewise evident in the subtitle of Georgio Riello's recent prizewinning book, Cotton: The Fabric that Made the Modern World. For both Parthasarathi and Riello the critical turning point in the Industrial Revolution was the moment British manufacturers developed the technology that enabled them to compete with India for domination of the global market in printed cotton fabrics. Beckert's book continues this shift of emphasis, except that he ties cotton more closely to slavery-and, indirectly, back to sugar. To produce sugar you needed slaves, he notes, but to buy slaves you needed cotton. Long before the southern states produced a speck of fiber, indeed from the earliest decades of British involvement in the Atlantic slave trade, the English were hungrily buying up cotton from wherever they could get it. By 1780 the largest suppliers of English cotton were Brazil and the Caribbean-the traditional suppliers of sugar. Merchants tried to get planters to switch over to cotton, but sugar plantations required heavy capital investments, and slaveholders were reluctant to make the switch. If Beckert is right, sugar was an obstacle to English industrialization. He stands Williams on his head. ${ }^{23}$

The solution to the problem of an inadequate supply of cotton came unexpectedly from an unexpected place - the southern United States. If the 1780s were the turning point that so many historians - Williams, Seymour Drescher, David Brion Davis, and Christopher Brown-have suggested, it was not merely because the imperial crisis disrupted the sugar market. It was also because that was the moment southern slaveholders began producing cotton. Slavery satisfied the demands of merchants in ways that Indian and Egyptian producers could not, for only on highly rationalized slave plantations could workers be compelled to produce the volume and quality of cotton English manufacturers craved. At first low-country planters in South Carolina and Georgia rose to the challenge by switching from rice to Sea Island cotton. But their silky, long-staple fibers could not be cultivated inland, and it was not until 1793 that Eli Whitney made short-staple cotton a viable alternative by inventing a machine that efficiently plucked the seeds from the bolls. In Beckert's telling, the invention of the cotton gin was as much the end of a long and exasperating search for a steady supply of cotton as it was the beginning of a new era in the 
history of slavery. The expansion of slavery across the American South was but the latest phase in the history of a larger, more enduring empire of cotton.

New World slavery has long been seen as one of the "fruits" of merchant capital, but few accounts of how those fruits were cultivated achieve Beckert's level of chronological clarity and specificity. He follows English merchants as they moved across the globe, buying and selling cotton, encouraging producers to increase their output. Crucial to their ability to maneuver was the emergence of a powerful, militarized state that could shove aside native peoples and impose its will on its own colonies or strong-arm weaker nations into "diplomatic" concessions amenable to British commercial interests. In Beckert's hands, the abstract "preconditions" of industrial capitalism assume the form of concrete events in specific places by actual people with real names.

Yet as closely as he connects the history of merchant capitalists to the history of industrial capitalists, Beckert maintains the essential distinction between the two. Merchants laid the groundwork, but industrial capitalism really was a revolutionary new way of organizing society. Here it's tempting to discern Hobsbawm's influence on Beckert. For thousands of years human beings lived on the land, drawing their subsistence from agriculture-whether they worked as serfs, free peasants, indentured servants, or slaves. The Industrial Revolution upended the ancient primacy of agriculture. Beginning in England in the late eighteenth century, industrial life then spread across the northern United States in the nineteenth century, overtaking much of Europe and a good part of the globe by the twentieth century.

But the fact that this great transformation happened everywhere does not mean it happened everywhere in exactly the same way, and Beckert is not always careful about this. He seems to assume, for example, that because cotton was important for England's Industrial Revolution, it must have been equally important for the Industrial Revolution in the United States. But every industrial revolution is different. Hobsbawm made the point clearly. The British experience was "unique and unparalleled" in large part because it was the first nation to industrialize. "No other country had to make its industrial revolution alone, unable to benefit from the existence of an already established industrial sector of the world economy." 24 Though Beckert implies that the cotton textile industry played the same role in the US economy that it did in England, he doesn't really prove it. Like Baptist, Beckert falls back on the long-ago discarded claim that northern industrialization spread outward from the textile mills of New England. And in an equally common refrain among recent scholars, he cites statistics demonstrating that raw cotton was the nation's largest single export without realizing that this cuts against his own interpretation. If all the South's cotton was exported and all the exports were cotton, it could only mean that cotton was of no significance to northern industrialization. If the domestic market was a hundred times larger than the export market, trade statistics would be meaningless. ${ }^{25}$

Still, Beckert, alone among the historians under review, posits a fundamental conflict between the North and the South. For a long time, industrial 
capitalism based on wage labor existed in a kind of codependent relationship with the slave labor systems spawned by merchant capital, even though they were very different forms of social organization. But as Beckert notes, this is what made the interdependency of slavery and capitalism within the United States so explosive. Usually slave societies were separated from metropoles as colonies, or were themselves independent. Only in the United States did slavebased merchant capital occupy the same nation state as industrial capitalism, creating a familiar pattern of sectionalism we recognize as the North and the South. This tension necessarily led to a long struggle for control of the state.

Throughout the centuries-long evolution of the empire of cotton, capitalists whether merchant or industrial-relied on the state to advance and protect their interests. Beckert is particularly good on this point. Parthasarathi had already demonstrated that the British textile industry grew up under the protective wing of mercantilist legislation. Beckert agrees but pushes the argument further to make a point about capitalists in general. They have always relied on governments to rewrite the laws of property, to enforce contracts, to dispossess indigenous peoples, to build turnpikes and canals and railroads to serve their needs. The state created stable banking and currency systems and wrote the credit and lien laws that likewise benefited the capitalists. Notwithstanding the mythology of "free trade" and the minimal state, control of state power was always important to capitalists. Yet once industrial capitalists emerged with interests different from and increasingly hostile to the interests of merchant capitalists - as they did within the United States - a conflict could scarcely be avoided. For Beckert this is what the Civil War was all about, an almost Manichean struggle between the merchant capitalists of the South and the industrial capitalists of the North.

But does this adequately explain the sectional conflict? Having recounted the global search for any reliable source of supply, Beckert observes that merchants and industrialists didn't much care whether the cotton they needed was produced by Indian farmers, Egyptian peasants, southern slaves, white tenants, or black sharecroppers. "After all," Beckert writes, "cotton merchants and manufacturers, unlike southern planters and their government, were not invested in a particular source of cotton - the American South - nor in a particular system of labor to produce it-slavery. All they wanted was a secure and predictable supply of inexpensive cotton in the qualities they desired" (265). A decade after the Civil War ended there were no more slaves, but the South was producing more cotton than ever. The empire of cotton survived the war; slavery did not. Beckert is surely right about this, but it raises a problem he needs to address. Precisely because merchant capital - which he inexplicably rechristens "war capitalism" - was indifferent to the forms of social organization, it cannot explain why the labor system that was specific to the Old South became so controversial that it led to a Civil War. Merchant capitalists did not secede from the Union: Slaveholders did.

By collapsing slavery into the broader category of "war capitalism," Beckert ends up with a peculiarly truncated account of the Civil War. He 
pays a great deal of attention to the state, but almost no attention to politics. Perhaps this is because the politics of slavery did not pit "war capitalism" against industrial capitalism. They pit free labor, understood as self-ownership, against slave labor, understood as the right of "property in man." So Beckert's account has capitalists who needed the state but no political struggle-no reform movements, no political parties, no politicians determined to seize control of the central state and use it to supplant slavery with free labor. Here Beckert departs significantly from Hobsbawn, for whom the "Age of Revolution" had a double character - it was an age of Industrial Revolution and an age of bourgeois revolution, and the two were closely connected. What Beckert gives us, by contrast, is a structural conflict between competing systems - merchant and industrial capitalism - without the agents who acted politically on behalf of these competing systems. But systems don't go to war, people do.

Beckert makes a compelling case for the Civil War as a major turning point in the global history of cotton, but there's no Republican Party that makes it happen. Instead, when the war comes, something unbelievable occurs: The capitalist revolutionaries who spent decades-centuries even-mobilizing state power to do their bidding responded to Fort Sumter by falling asleep for four years. At the moment of their greatest triumph, they went into a trancelike state and did absolutely nothing to establish the supremacy of free labor and destroy slavery. In Beckert's account, the War Department never instructed its commanders to emancipate slaves coming within its lines. Congress never made it a crime for Union soldiers to return slaves to their owners. Treasury never oversaw the establishment of free labor systems in Union-occupied territory. Benjamin Butler was never told to establish a wage labor system in Louisiana; he didn't really draft contracts specifying wage rates and working conditions. The Republicans in Congress and the White House did nothing. Instead, the capitalists took control of the central state in 1861, went to bed, and woke up in 1865 only to discover that the slaves had miraculously freed themselves, with no help whatsoever from the state. Only then, when the war was over and slavery was abolished, did the capitalists come back to life, reassert their control of the state, and restart their revolutionary transformation of the southern countryside.

In a way, Empire of Cotton is the mirror image of The Half Has Never Been Told. Beckert has the most persuasive account of the importance of state power, but he lacks Baptist's much firmer grasp of the politics of slavery. Yet their accounts of slavery's destruction bear a curious resemblance. Having attributed near total power to the masters, having cast so much doubt on the efficacy of slave resistance, Baptist rather incongruously invokes the familiar claim that "the slaves freed themselves." Where Beckert's normally aggressive capitalists fell asleep during the Civil War, Baptist's demoralized slaves suddenly rose up. Yet neither author so much as attempts the kind of political history required to make their claims plausible. A "global history" of slavery in wartime would show that war has led to mass enslavement far more often than to mass 
emancipation, so it's not enough to say that southern slaves took advantage of the opportunities created by the Civil War. What made the Civil War different was that the Union army was forced to comply with the antislavery policies coming out of Washington. To what extent did those policies create the "opportunities" for slaves to emancipate themselves? Why did so many federal policies depend on slave resistance to be effective? Why did the War Department focus on enlisting slaves from the same states Lincoln was putting the most pressure on to abolish slavery? In truth, historians have scarcely begun to appreciate the political significance of black troops. Unless you're prepared to connect the history of slave resistance to the politics of emancipation and abolition, broad pronouncements to the effect that "the slaves freed themselves" amount to little more than empty rhetorical gestures.

Collectively these books destroy whatever was left of the mythical version of an Old South that resisted the money-grubbing values of the market. If anything, southern slave society stood out by the extremity and ruthlessness of its exploitation. It was the worst of all possible worlds. Wage earners were driven to work by economic necessity because they no longer possessed the means of production. Slaves likewise had no claim on the land they worked, but their labor was nevertheless directly coerced by the legal power the masters exercised as a near-absolute right of property. Factory workers who didn't keep up could be fired, but they were not routinely stripped to the waist and whipped. (Robert Brenner says that the capitalist's ability to dismiss a worker was the most powerful motivator of labor ever devised.) The commodification of labor power was one of the defining attributes of northern capitalism, but slavery pushed commodification to an unparalleled extreme by treating the workers themselves - rather than their labor power-as articles of commerce. And far from rendering the slave economy inefficient, recent scholarship suggests that the property right in slaves had the opposite effect. Moveable property in slaves sped up the transition from "frontier" settlements to fully functioning plantations even as mortgages on slaves forced masters into a ceaseless race to increase the productivity of their slaves. Yet these were attributes that distinguished the slave economy of the South from the free labor economy of the North. We can call them both "capitalist," but we can't say they were identical.

No doubt the slave economy was often closely connected to the industrial and financial interests of the North and Great Britain, but as Stephanie McCurry has pointed out, the fact that they were connected does not mean they were the same. The significance we choose to see in those connections depends on the question we're asking. If the goal is to expose unclean hands, the point is well taken and easily made. In the long and sordid history of Atlantic slavery, everybody's hands eventually got dirty. Muslims, Jews, and Christians-even Quakers-bought and sold slaves. Africans and Arabs, Europeans and Americans captured, sold, and exploited millions upon millions of slaves. Add to this already deplorable record the numerous connections to slavery and the slave trade, and the dirt splatters across the globe-from the 
East Asian merchants who flourished on the trade in silver dug by slaves out of the mines at Potosí to the South Asian peasants who sold their cloth to Europeans who then exchanged it on the African coast for slaves destined for the plantations of the New World, where they produced the sugar that sweetened the tea that warmed the stomachs of New England farmers or was distilled into the rum that tranquilized the exploited proletarians of industrializing England. Across the Atlantic and throughout the northern United States the economic landscape was peppered with bankers, merchants, and manufacturers large and small who in one way or another profited from slavery. Trace all the linkages, follow all the connections, and there's no stopping point. If the recent spate of books on slavery and capitalism tell us anything, they tell us that if you take everybody tainted by slavery out of modern history there's not much history left.

But tracing connections will not be enough if we're asking how significant slavery and the slave trade were to the economic development of the United States. An answer to that question requires a different kind of research-different methods of inquiry focused on different places and grounded in different sources - than any of these authors have undertaken. It will require more nuance and less rhetoric, careful distinctions rather than grandiose declamations. When Baptist asserts that enslaved African Americans "built the modern United States, and indeed the entire modern world," he doesn't allow for the possibility that it was capitalism that made slavery profitable, not the other way around. He has the cart pulling the horse. When he says that southern slavery "made the entire world of white people wealthy," he fails to notice that the same forces that enslaved millions of Africans also impoverished countless English proletarians and reduced millions of Eastern European peasants to an unusually harsh "second serfdom." It's as if there were no "poor whites" in the Old South, or as though generations of southern poverty-black and whitewere not part of slavery's legacy to the New South. Statements of the sort Baptist makes are so unqualified that they practically invite disbelief and thus undercut what is surely the most important contribution these authors have made. After decades of arid cultural studies it's a relief to see a generation of smart historians take up anew the question of slavery and capitalism. But the question is too important to be answered so cavalierly.

And at some point, they're all going to have to do a better job of accounting for the Civil War, ideally in a way that brings the debate over slavery and capitalism into closer alignment with the debate over slavery and the sectional crisis. Consider, for example, a crucial asymmetry in the politics of slavery. As the North grew stronger, it was increasingly common for northern politicians to advocate federal policies designed to bring about the "ultimate extinction" of southern slavery. In this sense, antislavery politics was inherently revolutionary: No matter how moderately they expressed their views, antislavery northerners were calling for nothing less than the overthrow of a powerful slaveholding class and the destruction of the largest, wealthiest slave system in the world. Antislavery politicians could safely do this because their own economy was 
not threatened by the destruction of slavery. Northerners wanted cotton, but all things considered, they preferred their cotton grown by free laborers rather than slaves.

The slaveholders could not respond in kind. Proslavery politicians may have convinced themselves that grass would grow on the streets of New York and Philadelphia if the North dared make war on King Cotton, but the North had no intention of making war on cotton. It made war on slavery, secure in the conviction that emancipated laborers would keep the cotton coming-and it was the Yankees who were proved right. For all the proslavery bluster, the Old South never produced a popular movement calling for the abolition of free labor. Here and there eccentric intellectuals predicted the imminent demise of "free society," but not even the most bellicose proslavery politicians advocated policies designed to bring about the "ultimate extinction" of capitalism. They couldn't, because the destruction of capitalism necessarily entailed the destruction of the market for nearly all the commodities produced by slaves. This made proslavery politics, no matter how aggressive, inherently defensive. Southern leaders struggled to insulate slavery from the revolutionary threat of capitalism. They demanded federal protection of slavery, not a federal assault on free labor. If the slaveholders grew ever more belligerent in their increasingly extreme demands for federal protection of slavery, it was because they really did face an existential threat to their way of life.

\section{NOTES}

1. The classic account and starting point for all modern discussions is Eric Williams, Capitalism and Slavery (Chapel Hill, 1944). Two important collection of essays capture much of the debate aroused by Williams: Barbara L. Solow and Stanley L. Engerman, eds., British Capitalism and Caribbean Slavery: The Legacy of Eric Williams (Cambridge, 1987); Joseph E. Inikori and Stanley L. Engerman, eds., The Atlantic Slave Trade: Effects on Economies, Societies, and Peoples in Africa, the Americas, and Europe (Durham, NC, 1992). The quotation is from Solow, "Caribbean Slavery and the Industrial Revolution," in Solow and Engerman, British Capitalism and Caribbean Slavery, 72. My own thinking is close to Robin Blackburn, The American Crucible: Slavery, Emancipation and Human Rights (London, 2011), especially chapter 4, where Blackburn emphasizes that the capitalist transformation of the countryside preceded the Industrial Revolution without denying the various ways that slavery stimulated the growth of British industry.

A different tradition, derived from Max Weber, explains Europe's, and especially England's, economic divergence as a product of political and cultural rationalization. For recent examples of such cultural explanations, see Joel Mokyr, The Enlightened Economy: Britain and the Industrial Revolution, 1700-1850 (London, 2009); Deirdre N. McCloskey, Bourgeois Dignity: Why Economics Can't Explain the Modern World (Chicago, 2010). This approach has not gone uncontested, particularly by scholars more familiar with the histories of India and China. See, for example, C. A. Bayly, The Birth of the Modern World: 1780-1914 (Malden, MA, 2003); Prasannan Parthasarathi, Why Europe Grew Rich and Asia Did Not: Global Economic Divergence, 1600-1800 (Cambridge, 2011). For the global perspective see, among many others, Kenneth Pomeranz, The Great Divergence: China, Europe, and the Making of the Modern World Economy (Princeton, 2001).

2. Kenneth Pomeranz, The Great Divergence: China, Europe, and the Making of the Modern World Economy (Princeton, 2001); Parthasarathi, Why Europe Grew Rich and Asia Did Not. 
3. The most sustained defense of the classic "Williams Thesis" is undoubtedly Joseph E. Inikori, Africans and the Industrial Revolution: A Study in International Trade and Economic Development (Cambridge, 2002). From a very different perspective Ronald Findlay nevertheless endorses the Williams thesis in Ronald Findlay and Kevin H. O'Rourke, Power and Plenty: Trade, War, and the World Economy in the Second Millennium (Princeton, 2007), 344-347.

4. Maurice Dobb, Studies in the Development of Capitalism (New York, 1947); Rodney Hilton, Introduction to The Transition from Feudalism to Capitalism (London, 1976); T. H. Aston and C. H. E. Philpin, eds., The Brenner Debate: Agrarian Class Structure and Economic Development in Pre-Industrial Europe (Cambridge, 1985); Robert Brenner, "Property and Progress: Where Adam Smith Went Wrong," in Marxist History-Writing for the Twenty-First Century, ed. Chris Wickham (Oxford, 2007), 49-111. With the partial exception of Eric Hobsbawm (see below), the transition debates were largely oblivious to the problem posed by the rise of New World slavery. Conversely, where Eric Williams was careful to define slavery in precise terms, he made no attempt to say what he meant by "capitalism." Not until Robin Blackburn and Joseph Inikori engaged the problem did the two debates effectively merge.

5. R. H. Hilton, "Capitalism - What's in a Name," Past \& Present 1 (1962): 32-43, at 40.

6. Jan DeVries, The Economy of Europe in the Age of Crisis, 1600-1750 (Cambridge, 1976), especially 75-82, 113-46 (quotations are from 145). See also Jan De Vries, The Industrious Revolution: Consumer Behavior and the Household Economy, 1650 to the Present (Cambridge, 2008).

7. Scholars who uncovered a "consumer revolution" in the eighteenth century largely ignored the fact that many of the "goods" consumed were produced by slaves. A pioneering exception is Sidney Mintz, Sweetness and Power: The Place of Sugar in Modern History (New York, 1985). At the time he was writing nobody questioned Williams' emphasis on sugar plantations, but recently scholars have suggested that cotton was more important.

8. Eric Hobsbawm, "From Feudalism to Capitalism," in The Transition from Feudalism to Capitalism, ed. Hilton et al., 163-64, originally published in Marxism Today (August 1962). For Hobsbawm it was but a short step to world-systems theory, which sees the capitalist "core" and the underdeveloped periphery as interconnected parts of a larger capitalist "system." The difference is that for Hobsbawm the capitalist transformation of the English countryside necessarily preceded the creation of the world system.

9. Robert Brenner and Christopher Isett, "England's Divergence from China's Yangzi Delta: Property Relations, Microeconomics, and Patterns of Development," The Journal of Asian Studies 61 (2002), 609-62.

10. Gavin Wright, The Political Economy of the Cotton South: Households, Markets, and Wealth in the Nineteenth Century (New York, 1978). On the role of debt in the slave economy, see John J. Clegg, "Slavery and Capitalism," Critical Historical Studies 2 (2015), 281-304.

11. David Weiman, "The First Land Boom in the Antebellum United States: Was the South Different?" in Structures and Dynamics of Exploitations: Studies in Social and Economic History, vol. 5, ed. Erik Aerts (Louvain, 1990), 27-39; Gavin Wright, Slavery and American Economic Development (Baton Rouge, 2006).

12. Robert E. Gallman, "Self-Sufficiency in the Cotton Economy of the Antebellum South," in The Structure of the Cotton Economy of the Antebellum South, ed. William N. Parker (Washington, D.C., 1970), 5-23. Self-sufficiency in foodstuffs did not preclude significant southern purchases of shoes, clothing, or farm implements from the North, though these southern purchases represented a relatively small and declining proportions of sales. If we assume that slaves on southern plantations wore as many shoes as workers in Chicago or New York - that is, in proportion to the number of slaves in the US population-it would mean that purchases for slaves accounted for about eleven percent of the shoes manufactured in the North. That proportion was shrinking over time because northern population growth outpaced southern growth. When factory owners in New England mechanized production in the 1850 s, they did so in response to the rapidly expanding northern market, not the declining southern market.

13. Robert William Fogel, Without Consent or Contract: The Rise and Fall of American Slavery (New York, 1989), 78-79. 
14. Philip D. Morgan, "Task and Gang Systems: The Organization of Labor on New World Plantations," in Work and Labor in Early America, ed. I. Stephen Innes (Chapel Hill, 1988), 189-220; John Hebron Moore, The Emergence of the Cotton Kingdom in the Old Southwest: Mississippi, 1770-1860 (Baton Rouge, 1988); Peter Coclanis, "How the Low Country Was Taken to Task," in Slavery, Secession, and Southern History, ed. Robert Louis Paquette and Louis A. Ferleger (Charlottesville, VA, 2000), 59-78.

15. Alan L. Olmsted and Paul W. Rhode, Creating Abundance: Agricultural Innovation and American Agricultural Development (Cambridge, 2008).

16. Richard S. Dunn, A Tale of Two Plantations: Slave Life in Jamaica and Virginia (Cambridge, MA, 2014), 297-98.

17. There is now an impressive body of scholarship demonstrating that the capitalist transformation of the North began in the countryside. For a lucid summary of the scholarly debate, see Charles Post, The American Road to Capitalism: Studies in Class-Structure, Economic Development and Political Conflict, 1620-1877 (Chicago, 2011), 37-102. See also David R. Meyer, The Roots of American Industrialization: Creating the North American Landscape (Baltimore, 2003).

18. Robert J. Steinfeld, The Invention of Free Labor: The Employment Relation in English and American Law and Culture, 1350-1870 (Chapel Hill, 1991); Gavin Wright, Slavery and American Economic Development (Baton Rouge, 2006), 49-55 (quotation on 123).

19. No doubt the southern trade had been vitally important to the northern colonies in the eighteenth century, but by the American Revolution the focus of northern commerce had already shifted away from the Caribbean trade to the trans-Atlantic trade with Great Britain.

20. Charles L. Perdue, Jr., Thomas E. Barden, and Robert K. Phillips, eds., Weevils in the Wheat: Interviews with Virginia Ex-Slaves (Charlottesville, 1976), 151-54.

21. Richard Holcombe Kilbourne, Jr., Debt, Investment, Slaves: Credit Relations in East Feliciana Parish, Louisiana, 1825-1885 (Tuscaloosa, AL, 1995); Bonnie Martin, "Slavery's Invisible Engine: Mortgaging Human Property," Journal of Southern History 76 (2010): 81766. Research indicates that a majority of the mortgages on slaves were personal loans between neighbors.

22. Though he relies less on vulgarity than Johnson and Baptist, Beckert does not resist the urge to make up new words for familiar things. He replaces "merchant capitalism" with "war capitalism," for example, without explaining why or what difference it makes. Here I stick to "merchant capitalism," the term widely used by scholars.

23. Parthasarathi, Why Europe Developed; Giorgio Riello, Cotton: The Fabric the Made the Modern World (Cambridge, 2013).

24. E. J. Hobsbawm, Industry and Empire: From 1750 to the Present Day (Harmondsworth, 1968), 20-21. For a more recent reaffirmation of the point, see Post, The American Road to Capitalism, 30-31.

25. Robert E. Lipsey, "U.S. Foreign Trade and the Balance of Payments, 1800-1913," in The Cambridge Economic History of the United States, vol. 2, The Long Nineteenth Century, ed. Stanley Engerman and Robert Gallman (Cambridge, 2000), 685-732. Lipsey calculates that exports accounted for six percent of the GDP in the first half of the nineteenth century. 